\title{
ASSOCIATION BETWEEN THE DRD2-141C INSERTION/DELETION POLYMORPHISM AND SCHIZOPHRENIA
}

\author{
Quirino Cordeiro', Jacqueline Siqueira-Roberto ${ }^{2}$, Stevin Zung ${ }^{3}$, Homero Vallada ${ }^{4}$
}

\begin{abstract}
Epidemiological studies have demonstrated that the genetic component is an important risk factor for the development of schizophrenia. The genes that codify the different compounds of the dopaminergic system have created interest for molecular investigations in patients with schizophrenia because the antipsychotic drugs, especially those of first generation, act on this cerebral system. Thus the aim of the present study was to investigate the possible association between the -141 Ins/Del (rs1799732) polymorphism of the dopamine receptor type 2 (DRD2) and schizophrenia. The distribution of the alleles and genotypes of the studied polymorphism was investigated in a sample of 229 patients and 733 controls. There were statistical differences in the allelic $\left(\chi^{2}=9.78 ; p=0.001\right)$ and genotypic genotypic $\left(\chi^{2}=12.74 ; p=0.001\right)$ distributions between patients and controls. Thus the $-141 \mathrm{C}$ Ins/Del polymorphism of the DRD2 gene (allele Ins) was associated to the SCZ phenotype in the investigated sample.
\end{abstract}

KEY WORDS: dopamine, genetics, D2, receptor, schizophrenia.

\begin{abstract}
Associação entre o polimorfismo -141C Ins/Del do gene do DRD2 e esquizofrenia
Resumo - Estudos epidemiológicos têm demonstrado que o componente genético é um importante fator de risco para o desenvolvimento de esquizofrenia. Os genes que codificam os diferentes componentes do sistema dopaminérgico passaram a despertar interesse para os estudos moleculares em pacientes com esquizofrenia, devido ao fato dos antipsicóticos, em especial os de primeira geração, exercerem sua ação nesse sistema. Assim, o objetivo do presente estudo foi investigar a possivel associação entre polimorfismo -141C Ins/Del (rs1799732) do gene do receptor dopaminérgico tipo 2 (DRD2) e esquizofrenia. Um total de 229 pacientes e 733 controles pareados para sexo e idade foi selecionado com o objetivo de investigar a distribuição dos alelos e genótipos do polimorfismo investigado entre os grupos de pacientes e controles. Houve diferença estatisticamente significante nas distribuições alélica $\left(\chi^{2}=9,78 ; p=0,001\right)$ e genotípica $\left(\chi^{2}=12,74 ; p=0,001\right)$ entre pacientes e controles. Assim, o polimorfismo -141C Ins/Del do gene do DRD2 (alelo Ins) está associado à esquizofrenia na amostra estudada.
\end{abstract}

PALAVRAS-CHAVE: dopamina, genética, D2, receptor, esquizofrenia.

Schizophrenia (SCZ) is a chronic psychiatric disorder marked by psychotic symptoms, alterations of thought, affect, volition and behavior. The average lifetime prevalence is about $1 \%$ in general population. Family, twin and adoption studies have suggested that there is an important participation of a genetic component on the etiology of SCZ. The mode of inheritance is complex and nonMendelian (polygenic-environmental interaction). The role of a single relevant gene must be small, thus associa- tion studies, involving case-control approaches, have been employed to evaluate the allelic variations at specific candidate genes which may be implicated in the etiopathology of the disorder'. Some of the most investigated genes in studies of susceptibility to SCZ are those that code for proteins of the dopaminergic system because the evidences of the role of central dopamine pathways in the pathophysiology of the disorder ${ }^{3,4}$. Stimulant drugs, such as cocaine and amphetamine, that block reuptake of do-

Genetics and Pharmacogenetics Program (PROGENE), Department of Psychiatry, University of São Paulo Medical School, São Paulo SP, Brazil: 'MD, PhD, Researcher; ${ }^{2} \mathrm{BSc}$, Researcher; ${ }^{3} \mathrm{MD}, \mathrm{MSc}, \mathrm{PhD}$, Researcher; ${ }^{4} \mathrm{MD}$, PhD, Coordinator.

Received 16 September 2008, received in final form 8 December 2008. Accepted 20 February 2009.

Dr. Quirino Cordeiro - Rua Cônego Eugênio Leite 594 / 174 - 05414-000 São Paulo SP - Brasil. E-mail: qcordeiro@yahoo.com 
pamine or facilitate its release on neuronal synapses, may induce psychotic symptoms ${ }^{5}$. L-DOPA has also been implicated in psychotic symptoms through variable release of dopamine into the synapse ${ }^{6}$. On the other hand, some antipsychotic drugs correlate their efficacy with their action at dopaminergic receptors, especially blocking the subtype receptor D2 (DRD2) ${ }^{7}$. The DRD2 is a seven transmembrane $G$ protein linked receptor that binds dopamine and inhibits adenylate cyclase ${ }^{8}$, acting as an autoreceptor on dopaminergic cell bodies and as a postsynaptic receptor on dopaminergic targets ${ }^{9,10}$. In addition, there has been postulated that DRD2-binding density is increased in the brains of SCZ patients".

Therefore the DRD2 seems to play an important role in the expression of SCZ and consequently its gene (DRD2) has been considered a promising candidate risk gene for the disorder. DRD2 is localized to chromosome 11q22$\mathrm{q} 23^{12}$, a region of the genome that was reported as highly suggestive of linkage to SCZ in a recent series of meta-analyses ${ }^{13}$. Thus, there are converging biological, clinical, and genetic evidences implicating DRD2 as a viable candidate gene for genetic susceptibility for SCZ. Several genetic polymorphisms have been investigated as risk factor for SCZ. One of the most interesting investigated polymorphism of the DRD2 is a cytosine (C) insertion/ deletion in nucleotide position -141 of the 5 ' promoter region (-141C Ins/Del). The $-141 \mathrm{C}$ Ins/Del is a functional polymorphism and has been demonstrated to alter gene expression in vitro ${ }^{14}$. The deletion of the nucleotide was reported to reduce transcription by an average of $68 \%$ in two cell lines ${ }^{14}$.

Thus in the present study, the functional DRD2 polymorphism -141 Ins/Del (rs1799732) located in the promoter region of the gene was investigated as a possible risk factor for SCZ.

\section{METHOD}

\section{Sample}

Our sample was consisted of 229 (male=148: 64.63\%; female $=81: 35.37 \%$ ) Brazilian SCZ patients, and recruited at the Institute of Psychiatry, Hospital das Clínicas, University of São Paulo Medical School (SCZ subtypes: paranoid: 68.98\%, hebephrenic: $21.63 \%$, residual: $7.35 \%$, undifferentiated: $1.22 \%$, catatonic: 0.82 ). The diagnosis of SCZ was made according to DSM-IV ${ }^{15}$ criteria, based on a clinical interview conducted by a psychiatrist. A total of 733 (male=496: 67.67\%; female=237: 32.33\%) healthy control subjects were selected from unrelated subjects admitted to the Blood Donation Center of the "Fundação Pró-Sangue" of the University of São Paulo Medical School.

All patients and control subjects provided written informed consent for taking blood samples. Ethical approval for the study was obtained from the Ethics Committee at the Hospital das Clínicas, University of São Paulo Medical School (CAPPesq).

\section{DNA extraction}

Blood samples $(20 \mathrm{~mL})$ were collected from all participants of the study, and DNA was extracted from leukocytes using the "salting out" protocol ${ }^{16}$.

\section{Genotyping}

Genotyping of the investigated polymorphism for this study was performed blind to the clinical status of the individuals by using an amplifluor assay, and was performed under contract by Prevention Genetics (USA) (www.preventiongenetics.com).

\section{Statistical analysis}

The statistical power of the sample was evaluated using the CaTS Program (Center for Statistical Genetics - The University of Michigan) (http://www.sph.umich.edu/csg/abecasis/CaTS/ index.html).

A test for deviations from the Hardy-Weinberg equilibrium was performed using the HWE program ${ }^{17}$.

Allelic and genotypic distributions of the DRD2 polymorphism -141 Ins/Del were compared between 229 patients and 733 healthy controls. Chi-square test, used to investigate possible association between genotypes and alleles with SCZ, was performed by the Epilnfo version 6.0. The same statistical analysis was used to investigate difference between gender distribution between patients and controls. Differences of age between the groups of patients investigated were compared using student's t-test.

For all statistic tests the level of significance adopted was $\alpha<0.05$ or $5 \%$.

\section{RESULTS}

The power of the sample, based on 229 patients and 733 controls, disorder prevalence of $1 \%$, average allelic frequency around $20 \%$, multiplicative model with the genotype relative risk $=1.5$ and significance level of 0.05 , was $88 \%$.

For patients, mean age was $27.2 \pm 7.5$ years $(19-64)$ and median age was 26 years. For controls, mean age was $31.8 \pm$ 9.1 years (18-79) and median age was 30 years There was no statistical difference related to age between the groups of patients and controls $(p=0.12)$. Statistical analysis did not evidence difference related to gender distribution between the groups investigated as well $\left(\chi^{2}=0.51 ; p=0.43\right)$.

There were no significant deviations from Hardy-Weinberg equilibrium in the patients $(p=0.28)$ and controls $(p=0.19)$ samples for the -141 Ins/Del polymorphism.

There were statistical differences in the allelic $\left(\chi^{2}=9.78\right.$; $\mathrm{OR}=1.64,1.19<\mathrm{OR}<2.28 ; \mathrm{p}=0.001$; 1d.f.) and genotypic $\left(\chi^{2}=12.74 ; p=0.001 ; 2\right.$ d.f. $)$ distributions between patients and controls (Table).

\section{DISCUSSION}

The evidences of involvement of the dopaminergic system in the pathophisiology of SCZ have collaborat- 
Table. Distributions of the -141 Ins/Del alleles and genotypes frequencies in SCZ patients and controls samples.

\begin{tabular}{lcccc}
\hline & SCZ (\%) & Controls (\%) & $\chi^{2}$ & p Value \\
\hline Alleles & & & & \\
Ins & $404(88.21)$ & $1202(81.99)$ & & 0.001 \\
Del & $54(11.79)$ & $264(18.01)$ & 9.78 & \\
Total & $458(100)$ & $1466(100)$ & & \\
Genotypes & & & & \\
Ins/Ins & $183(79.91)$ & $498(67.94)$ & & \\
Ins/Del & $38(16.59)$ & $206(28.10)$ & 12.74 & \\
Del/Del & $8(3.49)$ & $29(3.96)$ & & \\
Total & $229(100)$ & $733(100)$ & & \\
\hline
\end{tabular}

ed to the investigation of genetic polymorphisms of this cerebral pathway and such disorder. The DRD2 polymorphisms have been the most investigated because the role of its receptor on atypical antipsychotics action, and interesting chromosomal positional of the gene. Among the DRD2 polymorphisms, the -141C Ins/Del may be considered a reasonable candidate risk gene for SCZ because of its regulatory activity. The first study investigating the $-141 C$ Ins/Del polymorphism of the DRD2 and SCZ was performed by Arinami et al..$^{14}$ and found an association between the disorder with the allele $-141 \mathrm{C}$ Ins. However, following investigations with different ethnical samples have shown controversial results finding also association with the opposite allele. These results could suggest that the importance of the $-141 \mathrm{C}$ Ins/Del polymorphism as a predisposing factor in SCZ may vary in different ethnical populations $^{18}$, what shows us the importance of the conduction of investigations in different ethnical context ${ }^{19}$.

However it could be premature to assess the validity of the association of SCZ and the studied polymorphism because it may be in tight linkage with another polymorphism which could influence the risk for the disorder. If the $-141 \mathrm{C}$ Ins/Del polymorphism is tightly linked with a polymorphism of risk for SCZ, different patterns of linkage disequilibrium may exist between different ethnical samples. Thus the $-141 \mathrm{C}$ Ins allele could be linked to the risk-conferring allele in some populations, but could be linked with the non-risk allele in others ${ }^{20}$.

As far as we know the present study is the first one investigating the polymorphism -141C Ins/Del in a Brazilian sample with SCZ. In populations of highly admixed ethnicity like the Brazilian one, we may face problems regarding ethnical stratification ${ }^{21}$. Physical characteristics in Brazil are not adequate predictors of genomic ancestry what difficult the ethnical matching in our case-controls studies ${ }^{22}$. However the fact that the present sample is in Hardy-Weinberg equilibrium indicates that our sample may not have important problems of population strat- ification ${ }^{23}$. Moreover ethnical matching conducted using genetic markers was performed in part of our sample in a case-control study with cocaine dependence and the results showed that despite the ethnic admixture in Brazil the ethnic stratification was not a bias in that case $e^{24}$.

In the present investigation, we found an association with the allele -141 CIns with SCZ. An increased frequency of the -141 CIns allele in patients with SCZ may contribute to the elevation of the DRD2 brain density. This evidence supports the dopamine hypothesis for SCZ, indicating that presence of the -141 CIns allele may be associated with dopamine hyperactivity, provoking psychotic symptoms ${ }^{25}$.

In conclusion, the results of the present investigation provide evidence for the association between -141C Ins/ Del polymorphism in the DRD2 5'promoter region and SCZ in our Brazilian sample. Furthermore, it is always possible that these polymorphisms are in linkage disequilibrium with non-identified genes that are in fact those contributing to the pathogenesis of SCZ or even with other polymorphisms within the DRD2. Our result suggests that the evaluation of this gene is important to clarify its role in SCZ development. More comprehensive polymorphisms coverage within the DRD2 is warranted. However to confirm the association of the 141C Ins/Del polymorphism with SCZ further studies must be conducted focusing on ethnical aspects. Moreover, differences in association of the -141C Ins/Del polymorphism and SCZ, found in different investigations, could be clarified by the analysis of larger case-control studies, additional family-based studies, and especially linkage disequilibrium mapping of $D R D 2$, which should be considered a high priority gene given its potentially important influence on the risk for SCZ.

\section{REFERENCES}

1. McGuffin P, Owen MJ, Farmer AE. The genetic basis of schizophrenia. Lancet 1995;346:678-682

2. Norton N, Williams HJ, Owen MJ. An update on the genetics of schizophrenia. Curr Opin Psychiatry 2006;19:158-164. 
3. Cordeiro Q Jr, Junqueira R, Vallada H. Study of association between the ser-9-gly of the D3 dopaminergic receptor and schizophrenia. Arq Neuropsiquiatr 2001;59:219-222.

4. Cordeiro Q, Talkowski M, Wood J, Ikenaga E, Vallada H. Lack of association between VNTR polymorphism of dopamine transporter gene (SLC6A3) and schizophrenia in a Brazilian sample. Arq Neuropsiquiatr 2004;62:973-976.

5. Bell D. Comparison of amphetamine psychosis and schizophrenia. Br J Psychiatry 1965;111:701-707.

6. Murphy DL, Brodie HK, Goodwin FK, Bunney WE. Regular induction of hypomania by L-DOPA in bipolar manic-depressive patients. Nature 1971;229:135-136.

7. Seeman P. Atypical antipsychotics: mechanism of action. Can J Psychiatry 2002;47:27-38.

8. Kebabian JW, Calne DB. Multiple receptors for dopamine. Nature 1979;277:93-96.

9. Khan ZU, Mrzljak L, Gutierrez A, de la Calle A, GoldmanRakic PS. Prominence of the dopamine D2 short isoform in dopaminergic pathways. Proc Natl Acad Sci USA 1998;95: 7731-7736.

10. Usiello A, Baik JH, Rouge-Pont F, et al. Distinct functions of the two isoforms of dopamine D2 receptors. Nature 2000;408: 199-203.

11. Seeman P. Dopamine receptors and the dopamine hypothesis of schizophrenia. Synapse 1987;1:133-152.

12. Grandy D K, Marchionni MA, Makam H, et al. Cloning of the cDNA and gene for a human D2 dopamine receptor. Proc Nat Acad Sci 1989;86:9762-9766.

13. Lewis CM, Levinson DF, Wise LH, et al. Genome scan metaanalysis of schizophrenia and bipolar disorder, part II: Schizophrenia. Am J Hum Genet 2003;73:34-48.

14. Arinami T, Gao M, Hamaguchi H, Toru M. A functional polymorphism in the promoter region of the dopamine $\mathrm{D}_{2}$ receptor gene is associated with schizophrenia. Hum Mol Genet 1997;6:577-582.

15. American Psychiatric Association. Diagnostic and statistical manual of mental disorders, 4th edn. Washington, DC: American Psychiatric Association, 1994.

16. Miller SA, Dykes DD, Polesky, HF. A single salting out procedure for extracting DNA from human nucleated cells. Nucleic Acids Res 1988;16:1215.

17. Ott J. Methods of analysis and resources available for genetic trait mapping. J Hered 1999;90:68-70.

18. Kampman O, Anttila S, Illi A, et al. Dopamine receptor D2 $-141 \mathrm{C}$ Insertion/Deletion polymorphism in a Finnish population with schizophrenia. Psych Res 2003;121:89-92.

19. Meira-Lima I, Michelon L, Cordeiro Q, Cho HJ, Vallada H. Allelic association analysis of the functional insertion/deletion polymorphism in the promoter region of the serotonin transporter gene in bipolar affective disorder. J Mol Neurosci 2005;27:219-224.

20. Glatt SJ, Faraone SV, Tsuang MT. DRD2 -141C insertion/deletion polymorphism is not associated with schizophrenia: results of a meta-analysis. Am J Med Genet 2004;128:21-23.

21. Silva MA, Cordeiro Q, Miracca EC, Guindalini C, Vallada H. Distribution of alleles of the VNTR polymorphism in the 3'untranslated region of the DAT1 gene (SLC6A3) in São Paulo/Brazil and its importance to genetic studies of neuropsychiatric disorders in ethically admixed populations. Rev Med Chil 2005;133:1392-1393.

22. Parra FC, Amado RC, Lambertucci JR, Rocha J, Antunes CM, Pena SD. Color and genomic ancestry in Brazilians. Proc Natl Acad Sci USA 2003;100:177-182.

23. Weiss ST, Silverman EK, Palmer LJ. Editorial: case-control association studies in pharmacogenetics. Pharmacogenomics J 2001;1:157-158.

24. Guindalini C, O'Gara C, Laranjeira R, et al. A GSTP1 functional variant associated with cocaine dependence in a Brazilian population. Pharmacogenet Genomics 2005;15:891-893.

25. Harrison PJ, Weinberger DR. Schizophrenia genes, gene expression, and neuropathology: on the matter of their convergence. Mol Psychiatry 2005;10:40-68. 